ISSN 1420-3049

www.mdpi.com/journal/molecules

Article

\title{
Phenolic Compounds and Antioxidant Activities of Liriope muscari
}

\section{Wen Jie Li ${ }^{1}$, Xian Long Cheng ${ }^{1}$, Jing Liu ${ }^{1}$, Rui Chao Lin ${ }^{1}{ }^{*}$, Gang Li Wang ${ }^{1, *}$, Shu Shan Du ${ }^{2}$ and Zhi Long Liu ${ }^{3}$}

1 National Institutes for Food and Drug Control, Beijing 100050, China;

E-Mail: 1wj115@163.com (W.J.L.)

2 State Key Laboratory of Earth Surface Processes and Resource Ecology, Beijing Normal University, Beijing 100875, China

3 Department of Entomology, China Agricultural University, Beijing 100193, China

* Authors to whom correspondence should be addressed; E-Mails: Linrch307@sina.com.cn (R.C.L.); duneer@163.com (G.L.W.); Tel.: +86-10-6709-5307 (R.C.L.); Fax: +86-10-6702-3650 (R.C.L.).

Received: 24 November 2011; in revised form: 24 January 2012 / Accepted: 31 January 2012 /

Published: 10 February 2012

\begin{abstract}
Five phenolic compounds, namely $N$-trans-coumaroyltyramine (1), $N$-transferuloyltyramine (2), $\mathrm{N}$-trans-feruloyloctopamine (3), 5,7-dihydroxy-8-methoxyflavone (4) and (3S)3,5,4'-trihydroxy-7-methoxy-6-methylhomoisoflavanone (5), were isolated from the fibrous roots of Liriope muscari (Liliaceae). Compounds 2-5 were isolated for the first time from the Liriope genus. Their in vitro antioxidant activities were assessed by the DPPH and ABTS scavenging methods with microplate assays. The structure-activity relationships of compounds $\mathbf{1}-\mathbf{3}$ are discussed.
\end{abstract}

Keywords: Liriope muscari; Liliaceae; antioxidant activity; homoisoflavone

\section{Introduction}

Antioxidant activity usually means the ability of a compound to delay, inhibit, or prevent the oxidation of oxidizable materials by scavenging free radicals and reducing oxidative stress [1]. Antioxidants can scavenge ROS (reactive oxygen species) to protect the cells from damage caused by the latter. At present, the most commonly used antioxidants include vitamin C (VC), vitamin E, butylated hydroxyanisole (BHA), butylated hydroxytoluene (BHT), propyl gallate and tert-butyl 
hydroquinone. However, some chemically synthesized antioxidants like BHA and BHT are now being restricted by legislation because of doubts over their possible toxic and carcinogenic effects [2]. Therefore, there is a growing interest in finding antioxidants from natural sources $[3,4]$. Assays based on the use of 1,1-diphenyl-2-picryl-hydrazyl (DPPH) and 2,2'-azino-bis(3-ethylbenzthiazoline-6sulfonic acid) (ABTS) radicals are among the most commonly used spectrophotometric methods for determination of the antioxidant capacity of foods, beverages, plant extracts and pure compounds due to the simple, rapid, sensitive, and reproducible procedures involved [5,6]. Phenolic compounds usually possess different antioxidant activity potentials because of their phenolic hydroxy groups which can act as a hydrogen or electron donor [7]. Phenolic acids, flavonoids and tannins are wellknown potential natural antioxidants [1]. The hunt for effective and safe antioxidants from natural products is considered to be a shortcut [8].

Liriope muscari (Decne.) Bailey (Liliaceae) is locally known in China as duantingshanmaidong. In China, the roots of this species are used locally as a substitute for Radix Ophiopogonis (maidong in Chinese) [9], especially in Fujian Province. Maidong is a traditional herbal medicine widely used in China as a tonic agent. Modern pharmacological investigations suggest that maidong also has an positive effect on various inflammation-related diseases [10]. Previous studies indicated that the main components in L. muscari include polysaccharides and steroidal glycosides [11-13]. In this paper, five phenolic compounds (Figure 1), including three amides [N-trans-coumaroyltyramine (1), $N$-transferuloyltyramine (2) and $N$-trans-feruloyloctopamine (3)], one flavone [5,7-dihydroxy-8-methoxyflavone (4)] and one homoisoflavanone [(3S)-3,5,4'-trihydroxy-7-methoxy-6-methylhomoiso-flavonone (5)] were isolated from L. muscari. Compounds 2-5 were isolated for the first time from the Liriope genus.

Figure 1. Structures of compounds isolated from L. muscari.

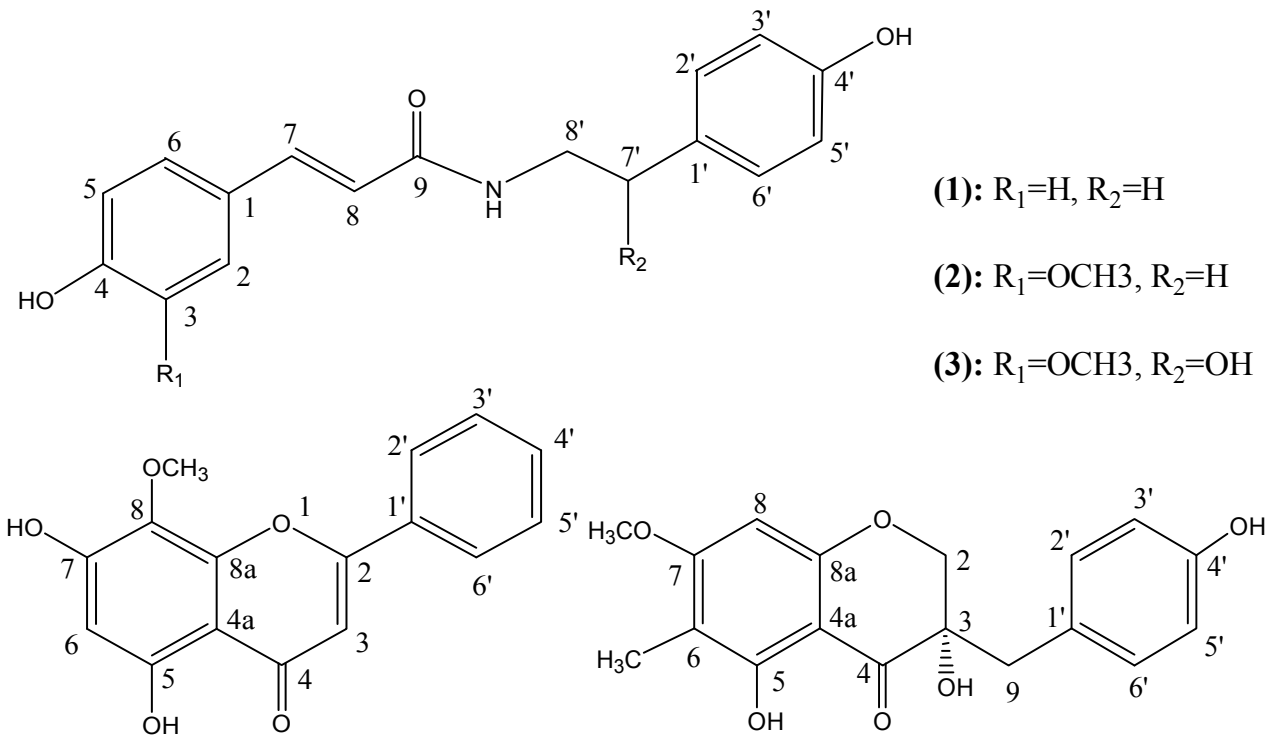

(4)

(5)

To our knowledge, this is the first time that the phenolic components of L. muscari have been studied. Their in vitro antioxidant activities were assessed by the DPPH and ABTS scavenging method. $N$-trans-feruloyltyramine ( $\mathrm{IC}_{50} 28.7,8.2 \mu \mathrm{g} / \mathrm{mL}$ ) and $N$-trans-feruloyloctopamine $\left(\mathrm{IC}_{50} 14.4,7.6 \mu \mathrm{g} / \mathrm{mL}\right.$ ) showed potential antioxidant activities. 


\section{Results and Discussion}

\subsection{Isolation and Characterization of Compounds $\mathbf{1 - 5}$}

The compounds were isolated using silica gel and Sephadex LH-20 gel column chromatography from $80 \%$ ethanol extract of $L$. muscari. The structures of compounds $\mathbf{1}-\mathbf{4}$ were characterized by examination of their ESI-MS, NMR (1H- and 13C-) data and comparison with literature reports.

Compound 5 was first isolated in 1985 from Ophiopogonis [14] (Liliaceae), a closely linked genus that can be easily confused with Liriope. In the original paper, the planar structure of compound $\mathbf{5}$ was identified by comparing the ${ }^{1} \mathrm{H}-\mathrm{NMR}$ data with that of (3S)-3,5,7-trihydroxy-4'-methoxy homoisoflavonone (eucomol, a typical homoisoflavonone isolated from Eucomis bicolor BAK. (Liliaceae) [15,16]). In our study, the structure was further confirmed using ${ }^{13} \mathrm{C}-\mathrm{NMR}$, APT and 2D-NMR techniques, including ${ }^{1} \mathrm{H}-{ }^{1} \mathrm{HCOSY}, \mathrm{HSQC}, \mathrm{HMBC}$ (Figure 2). The configuration at C-3 was determined to be $(S)$, similar to that of eucomol, based on the positive sign of its specific rotation [16,17]. For a long time, it was believed that there were no homoisoflavones in Liriope, so this is the first time a homoisoflavone has been isolated from the Liriope genus.

Figure 2. Key HMBC correlations of compound 5.

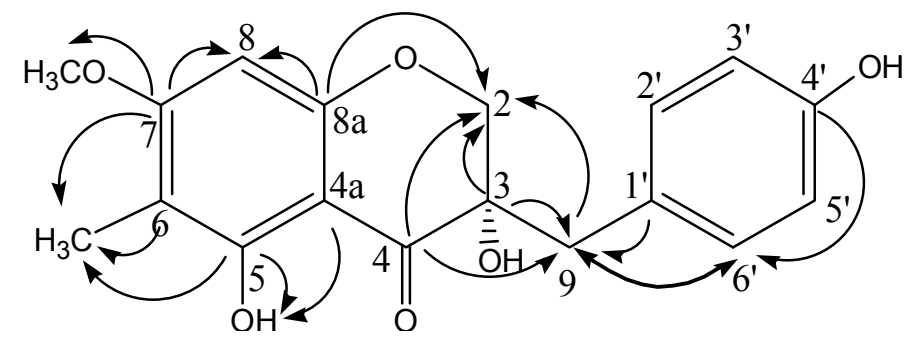

\subsection{In Vitro Antioxidant Activity}

\subsubsection{DPPH Scavenging Activity}

The 1,1-diphenyl-2-picrylhydrazyl radical (DPPH), which possesses an unpaired electron and exhibits a stable violet color in methanol solution (peak absorbance at $517 \mathrm{~nm}$ ), is commonly used as a reagent for evaluation of the free radical scavenging activity of antioxidants [18]. The DPPH assay is based on the reduction of DPPH in methanol solution in the presence of a hydrogen-donating antioxidant due to the formation of the non-radical form (DPPH-H) in the reaction [19].

Figure 3 shows the DPPH scavenging activities of compounds 1-5 and reference antioxidants at different concentrations $(12.5-100 \mu \mathrm{g} / \mathrm{mL})$. The test compounds exhibited different DPPH scavenging activities in a concentration-dependent manner. The scavenging effects of compounds $\mathbf{1}-\mathbf{5}$ and reference antioxidants on DPPH decreased in the following order: $\mathrm{VC}>$ compound $\mathbf{3}>$ compound $\mathbf{2}>$ BHT $>$ compound $\mathbf{4}>$ compound $\mathbf{1}>$ compound 5. The inhibition ratios at a concentration of $25 \mu \mathrm{g} / \mathrm{mL}$ are listed in Table 1 . Compounds 2 and 3 exhibited effective radical scavenging activity while compounds $\mathbf{1}, \mathbf{4}, \mathbf{5}$ showed very weak activity. 
Figure 3. DPPH scavenging activity of compounds 1-5 and reference antioxidants.

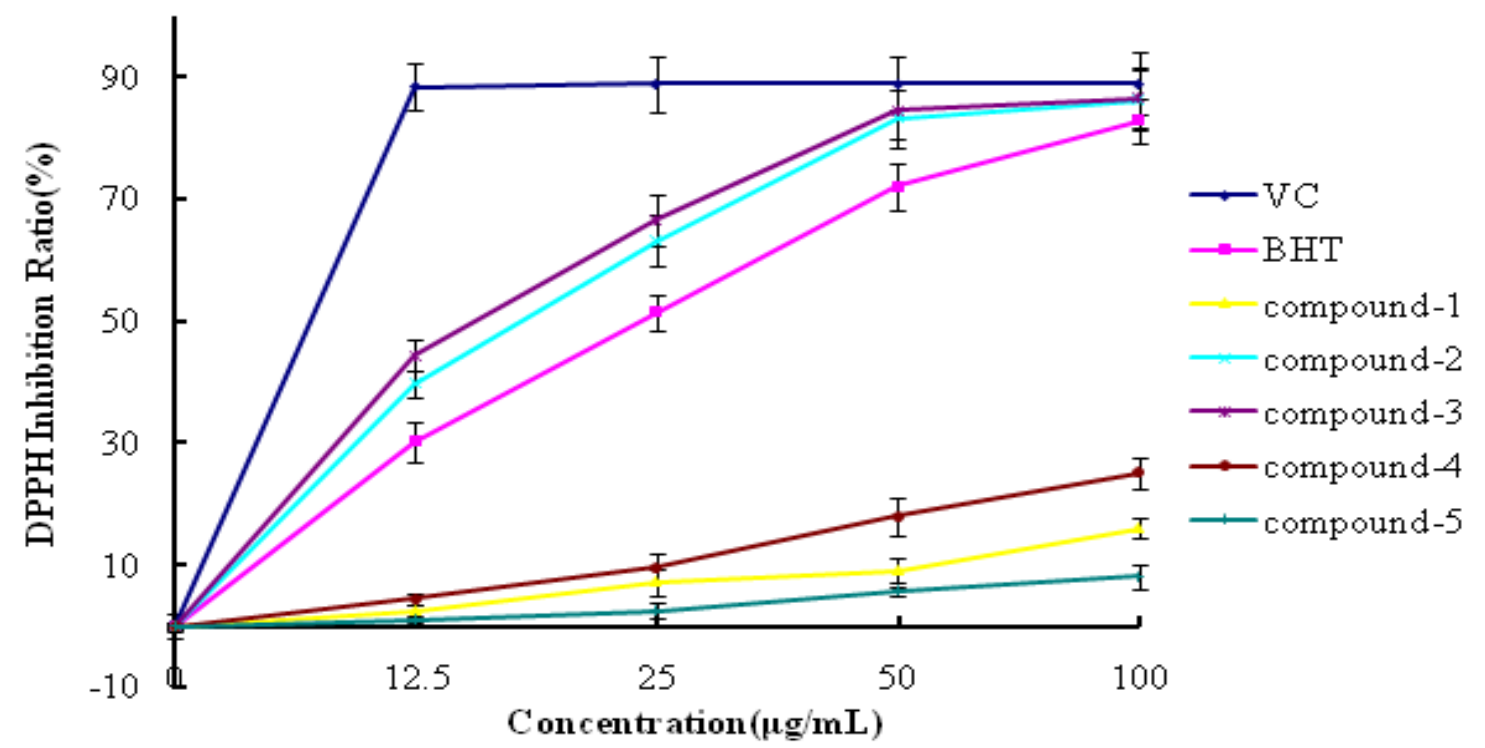

Scavenging activities of different concentrations of samples $(12.5-100 \mu \mathrm{g} / \mathrm{mL})$ were determined spectrophotometrically at $517 \mathrm{~nm}$. Results are means $\pm \mathrm{SD}$ of three duplicate measurements and followed by the Student's $t$-test. (VC: Vitamin C; BHT: butylated hydroxytoluene; DPPH: 1,1-diphenyl-2-picryl-hydrazyl free radical).

Table 1. The DPPH and ABTS inhibition ratio at the concentration of $25 \mu \mathrm{g} / \mathrm{mL}$.

\begin{tabular}{ccc}
\hline & $\begin{array}{c}\text { DPPH Inhibition } \\
\text { Ratio (\%) }\end{array}$ & $\begin{array}{c}\text { ABTS Inhibition } \\
\text { Ratio (\%) }\end{array}$ \\
\hline Compound 1 & $7.2 \pm 0.6$ & $32.7 \pm 1.6$ \\
Compound 2 & $63.2 \pm 3.6$ & $75.9 \pm 2.0$ \\
Compound 3 & $66.6 \pm 2.3$ & $70.0 \pm 3.2$ \\
Compound 4 & $9.6 \pm 1.2$ & $24.3 \pm 1.9$ \\
Compound 5 & $2.6 \pm 0.5$ & $16.8 \pm 1.7$ \\
VC & $88.9 \pm 4.5$ & $97.4 \pm 5.0$ \\
BHT & $51.5 \pm 3.1$ & $95.1 \pm 5.3$ \\
\hline
\end{tabular}

\subsubsection{ABTS Scavenging Activity}

In this assay, the 2,2'-azino-bis(3-ethylbenzthiazoline-6-sulfonic acid) (ABTS) radical, which has a peak absorbance at $734 \mathrm{~nm}$, should be preformed by mixing ABTS and potassium persulfate $\left(\mathrm{K}_{2} \mathrm{~S}_{2} \mathrm{O}_{8}\right)$. When antioxidants were added, the ABTS radical, which has a blue-green color, is reduced to ABTS (no color). Different decoloration abilities indicate different ABTS scavenging activities [20].

Figure 4 shows the ABTS scavenging abilities of compounds 1-5 and reference standards. The test compounds also exhibited different radical scavenging activities in a concentration-dependent manner like in the DPPH assay. The scavenging effects of compounds 1-5 and reference antioxidants on $\mathrm{ABTS}^{++}$decreased in the following order: $\mathrm{VC} \approx \mathrm{BHT}>$ compound $\mathbf{2}>$ compound $\mathbf{3}>$ compound $\mathbf{1}>$ compound $4>$ compound 5 . The inhibition ratios at concentration of $25 \mu \mathrm{g} / \mathrm{mL}$ are listed in Table 1 . Compounds $\mathbf{2}$ and $\mathbf{3}$ exhibited effective radical scavenging activity, while compounds $\mathbf{1}, \mathbf{4}$ and $\mathbf{5}$ showed relatively weak activity. 
Figure 4. ABTS scavenging activity of compounds 1-5 and reference antioxidants.

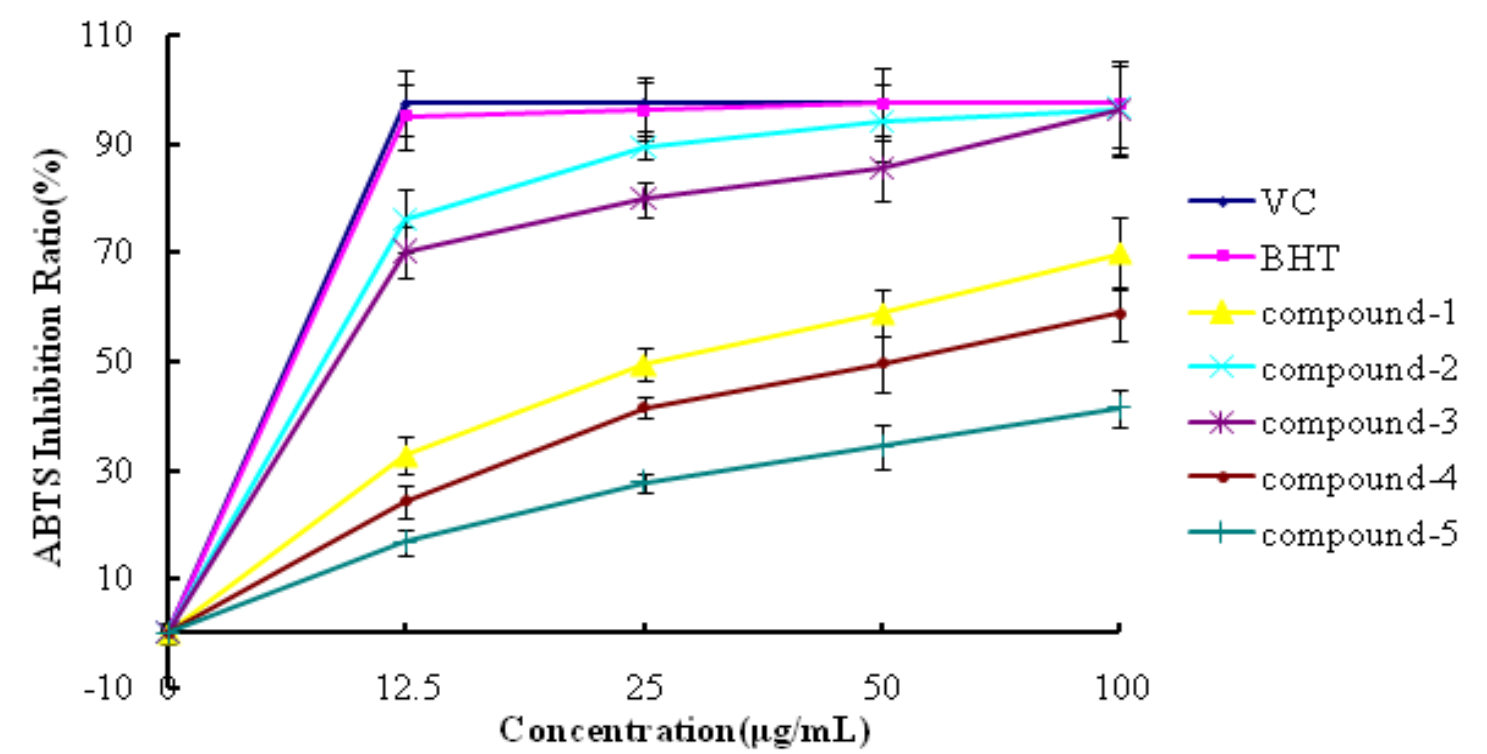

Scavenging activities of different concentrations of samples $(12.5-100 \mu \mathrm{g} / \mathrm{mL})$ were spectrophotometrically deternined at $734 \mathrm{~nm}$. Results are means $\pm \mathrm{SD}$ of three duplicate measurements and followed by the Student's $t$-test. (VC: Vitamin C; BHT: butylated hydroxytoluene; ABTS: 2,2'-azino-bis(3-ethylbenzthiazoline-6-sulfonic acid) radical.

In both methods, compounds 2 [21] and 3 [22] showed potential activity, while compounds $\mathbf{1}$ [23,24] and 4 [25] showed very weak antioxidant activity, which is consistent with the reported results. Furthermore, for compound 4, quantitative structure-activity relationship analysis [26] also suggested it would not show effective activity because of the absence of 3-OH and $o$-dihydroxy structure in the $\mathrm{B}$ ring, and less free -OH groups (only two) in the structure, which are required for high antioxidant activity. As for compound $\mathbf{5}$, its antioxidant activity has been previously evaluated using an on-line HPLC-DAD-CL method based on hydrogen peroxide elimination [27]. However, the results cannot be compared with our data due to the absence of any mention of the concentration used in that study.

It is interesting to investigate the structure-activity relationship for compounds $\mathbf{1}-\mathbf{3}$. These compounds have similar structures, but very different activities. Comparing their structures (Figure 1), the main differences are the substituents at $C-3\left(\mathrm{R}_{1}\right)$ and $\mathrm{C}-7^{\prime}\left(\mathrm{R}_{2}\right)$. Comparing the structures and activities of compounds $\mathbf{2}$ and $\mathbf{3}(p>0.05,25 \mu \mathrm{g} / \mathrm{mL})$ it is inferred that the presence of methyl group at C-7' seems to have some, but little influence on antioxidant activity. By comparing compounds $\mathbf{1}$ and 2 $(p<0.05,25 \mu \mathrm{g} / \mathrm{mL}$ ), it is inferred that the presence of methyl group at C-3 is the key factor that affects the activities, therefore, a radical scavenging activity mechanism represented by the reaction shown in Figure 5 is proposed, using DPPH as an example. Compounds $\mathbf{2}$ and $\mathbf{3}$ have two resonance structures $\mathrm{A}$ and $\mathrm{B}$ stabilizing the product, thereby exhibiting superior antioxidant activity than compound 1. As HPLC evaluation (Experimental section) indicates a relative purity between $90.1 \%$ and $96.7 \%$ for compounds $\mathbf{1}-\mathbf{3}$, potential synergistic effects from minor impurities could also contribute to the observed activity. 
Figure 5. The proposed reaction mechanism between DPPH' and compounds 1-3.

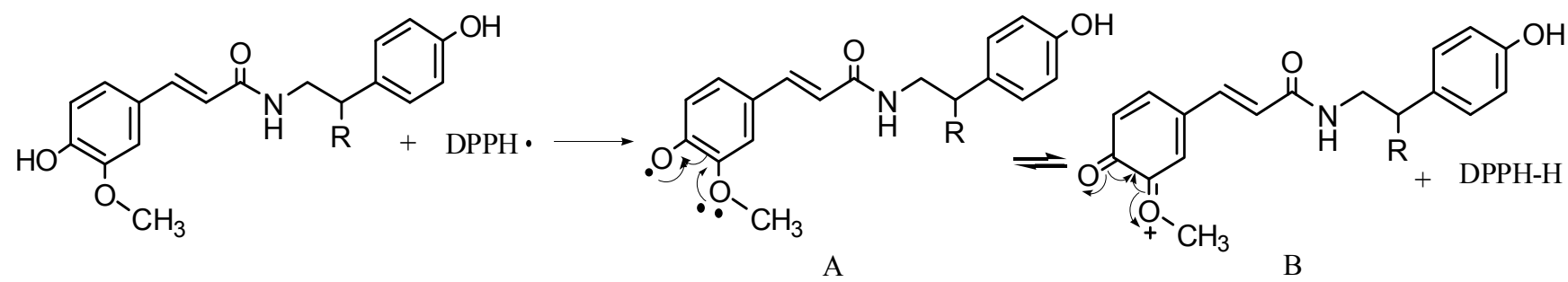

\section{Experimental}

\subsection{General}

${ }^{1} \mathrm{H}$ - and ${ }^{13} \mathrm{C}$-NMR spectra were recorded on Bruker Avance DRX 500 instrument using DMSO- $d_{6}$ or $\mathrm{CDCl}_{3}$ as solvent with TMS as internal standard. An Agilent 6320 Ion TRAP LC/MS was employed for MS analysis. The specific rotation was recorded on AUTOPOL IV Automatic Polarimeter (Rudolph, Hackettstown, NJ, USA). For the microplate assay, a SpectraMax 190 Absorbance Microplate Reader (Molecular Devices, Sunnyvale, CA, USA) and 96 Well Cell Culture Cluster (Costar, Corning, NY, USA) were used. 1,1-diphenyl-2-picrylhydrazyl (DPPH) and 2,2'-azino-bis(3ethylbenzthiazoline-6-sulfonic acid) (ABTS) were purchased from Sigma (Sigma-Aldrich GmbH, Stenheim, Germany). Sephadex LH-20 was purchased from Amersham Pharmacia Biotech AB (Uppsala, Sweden). Polyamide resin (100-200 mesh) was purchased from BeiJingZhongXiYuanDa Technical Co. Ltd. (Beijing, China). Silica gel (160-200 mesh, 200-300 mesh) for column chromatography was purchased from Qingdao Marine Chemical Plant (Shandong Province, China). All other chemicals were of analytical reagent grade and used without any further purification.

\subsection{Plant Material}

Fresh fibrous roots of L. muscari were collected from Quanzhou City, Fujian Province, China, in May 2010. The species was identified by Dr. Zhang. J. (National Institutes for Food and Drug Control, NIFDC for short). The voucher specimens were deposited at the herbarium of NIFDC. The roots were air-dried and ground to a powder using a grinding mill (Retsch Muhle, Haan, Germany).

\subsection{Compound Isolation}

In this part, there were mainly two procedures including enrichment and isolation. For the enrichment of phenolic compounds, polyamide resin was used. Polyamide is a commonly used stationary phase for the isolation of phenolic compounds. The enriching mechanism is based on the adsorption power from hydrogen bonds between carbonyl groups of the polyamide and the phenolic hydroxyl groups of target compounds or the polyamide amides and carbonyl groups of fatty acids, etc., The strength of adsorption is dependent on the number of phenolic hydroxyls exposed and their position in the molecule [28] and the power is strongest in water, while getting weaker when the ethanol concentration in the mobile phase is increased.

The detailed procedures are as follows: the powder $(2 \mathrm{~kg})$ was extracted three times with $80 \%$ hot ethanol $(1 \mathrm{~L})$, for $1 \mathrm{~h}$ each time. The extracts were concentrated to afford a syrup $(1 \mathrm{~kg})$, which was 
dissolved in $10 \%$ ethanol (4 L). Polyamide ( $1 \mathrm{~kg}$ ) was added into the solution and stirred about $1 \mathrm{~h}$ to make sure the phenolic compounds were adsorbed on the polyamide to some extent. Then the polyamide was centrifuged to dryness $(1,000 \times \mathrm{g}, 10 \mathrm{~min})$. Fresh water was used to rinse the polyamide several times till the water was nearly colorless. Then $95 \%$ ethanol was used to rinse the polyamide and the solution was collected. The ethanol solution was evaporated to dryness under reduced pressure to afford a solid residue ( $30 \mathrm{~g})$. The solid residue was chromatographed over a silica gel (160-200 mesh) column $\left(45 \times 6.0 \mathrm{~cm}\right.$ i.d.) with $\mathrm{CHCl}_{3} / \mathrm{MeOH}(20: 1$ to $8: 1)$ to afford 30 fractions (F01-F30). Fraction F03 (2.2 g) was subjected to Sephadex LH-20 column $(120 \times 2.5 \mathrm{~cm}$ i.d.) chromatography with $\mathrm{CHCl}_{3} / \mathrm{MeOH}(10: 1)$ to afford 11 subfractions (F0301-F0311). Then fraction F0308 (69 mg) was chromatographed over a silica gel column $(200-300 \mathrm{mesh}, 30 \times 2.0 \mathrm{~cm}$ i.d.) with petroleum/EtOAc (P/E 6:1 to 3:1) to afford compound 4 (10 mg, crystal, P/E 6:1) and compound 5 (8 mg, crystal, P/E 3:1). The purities were $96.3 \%$ and $97.2 \%$, respectively (HPLC, $254 \mathrm{~nm}$ with PDA detector). As for the isolation of compounds 1-3, fractions F10-F11 (500 mg), fractions F06-F08 (800 mg) and fractions F12-F14 (500 mg) were separated on a Sephadex LH-20 gel column $(120 \times 2.0 \mathrm{~cm}$ i.d. $)$ with $\mathrm{MeOH}$ to afford 11 subfractions (F1001-F1011), 19 subfractions (F0601-F0619), and 17 subfractions (F1201-F1217), respectively. Then subfractions F1006 (40 mg), F0609 (100 mg), F1205 (120 mg) were chromatographed over a silica gel column (200-300 mesh, $30 \times 2.0 \mathrm{~cm}$ i.d.) with P/E (1:1), P/E (3:2 to 1:1), P/E (1:1 to $1: 2)$ to afford compounds 1 (10 mg), 2 (8 mg) and 3 (15 mg). The purity of compounds 1-3 was 96.6\%, 90.1\% and 91.1\%, respectively (HPLC, $254 \mathrm{~nm}$ with PDA detector).

$N$-trans-coumaroyltyramine (1). White powder (petroleum/acetic ether). $\mathrm{R}_{\mathrm{f}} 0.65$ (acetic ether) ESI-MS: $m / z 284[\mathrm{M}+\mathrm{H}]^{+} . \mathrm{C}_{17} \mathrm{H}_{17} \mathrm{NO}_{3} .{ }^{1} \mathrm{H}-\mathrm{NMR}$ (DMSO-d, $\left.500 \mathrm{MHz}\right) \delta: 9.36(-\mathrm{OH}), 8.11(1 \mathrm{H}, \mathrm{t}, 5.0 \mathrm{~Hz},-\mathrm{NH})$, 7.39 (2H, d, $8.5 \mathrm{~Hz}, \mathrm{H}-2,6), 7.30$ (1H, d, $15.5 \mathrm{~Hz}, \mathrm{H}-7), 7.01\left(2 \mathrm{H}, \mathrm{d}, 8.0 \mathrm{~Hz}, \mathrm{H}-2^{\prime}, 6^{\prime}\right), 6.78$ (2H, d, $8.5 \mathrm{~Hz}$, H-3, 5), 6.67 (2H, d, 8.0 Hz, H-3', 5'), 6.38 (1H, 15.5 Hz, H-8), 3.31 (2H, m, H-8'), 2.64 (2H, t, 7.5 Hz, $\left.\mathrm{H}-7^{\prime}\right)$. The ${ }^{1} \mathrm{H}$ - and ${ }^{13} \mathrm{C}-\mathrm{NMR}$ (Table 2) spectral data are consistent with published data $[29,30]$.

$N$-trans-feruloyltyramine (2). Colourless oil (petroleum/acetic ether). $\mathrm{R}_{\mathrm{f}} 0.62$ (acetic ether) ESI-MS: $m / z 314[\mathrm{M}+\mathrm{H}]^{+} . \mathrm{C}_{18} \mathrm{H}_{19} \mathrm{NO}_{4} \cdot{ }^{1} \mathrm{H}-\mathrm{NMR}$ (DMSO- $\left.d_{6}, 500 \mathrm{MHz}\right) \delta: 9.46,9.21\left(\mathrm{C}_{4}-\mathrm{OH}, \mathrm{C}_{4^{\prime}}-\mathrm{OH}\right), 8.01$ $(1 \mathrm{H}, \mathrm{t}, 5.0 \mathrm{~Hz},-\mathrm{NH}), 7.31(1 \mathrm{H}, \mathrm{d}, 16.0 \mathrm{~Hz}, \mathrm{H}-7), 7.12(1 \mathrm{H}, \mathrm{s}, \mathrm{H}-2), 7.01\left(2 \mathrm{H}, \mathrm{d}, 8.0 \mathrm{~Hz}, \mathrm{H}-2^{\prime}, 6^{\prime}\right), 6.98$ $(1 \mathrm{H}, \mathrm{m}, \mathrm{H}-6), 6.78(1 \mathrm{H}, \mathrm{d}, 8.2 \mathrm{~Hz}, \mathrm{H}-5), 6.68\left(2 \mathrm{H}, \mathrm{d}, 8.0 \mathrm{~Hz}, \mathrm{H}-3^{\prime}, 5^{\prime}\right), 6.43$ (1H, $\left.15.5 \mathrm{~Hz}, \mathrm{H}-8\right), 3.80$ $\left(3 \mathrm{H}, \mathrm{s},-\mathrm{OCH}_{3}\right), 3.33\left(2 \mathrm{H}, \mathrm{m}, \mathrm{H}-8^{\prime}\right), 2.64\left(2 \mathrm{H}, \mathrm{t}, 7.5 \mathrm{~Hz}, \mathrm{H}-7^{\prime}\right)$. The ${ }^{1} \mathrm{H}-$ and ${ }^{13} \mathrm{C}-\mathrm{NMR}$ (Table 2) spectral data are consistent with published data $[31,32]$.

$N$-trans-feruloyloctopamine (3). Colourless oil (petroleum/acetic ether). $\mathrm{R}_{\mathrm{f}} 0.47$ (acetic ether) ESI-MS: $m / z 330[\mathrm{M}+\mathrm{H}]^{+} . \mathrm{C}_{18} \mathrm{H}_{19} \mathrm{NO}_{5} .{ }^{1} \mathrm{H}-\mathrm{NMR}\left(\mathrm{DMSO}-d_{6}, 500 \mathrm{MHz}\right) \delta: 9.47,9.32\left(\mathrm{C}_{4}-\mathrm{OH}, \mathrm{C}_{4^{\prime}}-\mathrm{OH}\right), 7.96$ $(1 \mathrm{H}, \mathrm{t}, 5.5 \mathrm{~Hz},-\mathrm{NH}), 7.31(1 \mathrm{H}, \mathrm{d}, 15.5 \mathrm{~Hz}, \mathrm{H}-7), 7.15\left(2 \mathrm{H}, \mathrm{d}, 8.5 \mathrm{~Hz}, \mathrm{H}-2^{\prime}, 6^{\prime}\right), 7.12(1 \mathrm{H}, \mathrm{s}, \mathrm{H}-2), 6.98$ $(1 \mathrm{H}, \mathrm{d}, 7.5 \mathrm{~Hz}, \mathrm{H}-6), 6.79(1 \mathrm{H}, \mathrm{d}, 8.5 \mathrm{~Hz}, \mathrm{H}-5), 6.72\left(2 \mathrm{H}, \mathrm{d}, 8.5 \mathrm{~Hz}, \mathrm{H}-3^{\prime}, 5^{\prime}\right), 6.55(1 \mathrm{H}, 15.5 \mathrm{~Hz}, \mathrm{H}-8)$, $4.54\left(1 \mathrm{H}, \mathrm{m}, \mathrm{H}-7^{\prime}\right), 3.80\left(3 \mathrm{H}, \mathrm{s},-\mathrm{OCH}_{3}\right), 3.38,3.18\left(2 \mathrm{H}, \mathrm{m}, \mathrm{H}-8^{\prime}\right)$. The ${ }^{1} \mathrm{H}-$ and ${ }^{13} \mathrm{C}-\mathrm{NMR}$ (Table 2) spectral data are consistent with published data $[32,33]$.

5,7-Dihydroxy-8-methoxyflavone (4). Yellow needle crystal (petroleum/acetic ether). $\mathrm{R}_{\mathrm{f}} 0.40$ (P/E 2:1) ESI-MS: $m / z 283[\mathrm{M}-\mathrm{H}]^{-} . \mathrm{C}_{16} \mathrm{H}_{12} \mathrm{O}_{5} .{ }^{1} \mathrm{H}-\mathrm{NMR}$ (DMSO- $\left.d_{6}, 500 \mathrm{MHz}\right) \delta: 12.52(1 \mathrm{H}, \mathrm{s}, 5-\mathrm{OH}), 10.87$ $(1 \mathrm{H}, \mathrm{s}, 7-\mathrm{OH}), 8.08$ (2H, d, $\left.6.5 \mathrm{~Hz}, \mathrm{H}-2^{\prime}, 6^{\prime}\right), 7.62$ (3H, m, H-3', 4', 5'), $7.02(1 \mathrm{H}, \mathrm{s}, \mathrm{H}-3), 6.32(1 \mathrm{H}, \mathrm{s}$, 
H-6), $3.86\left(3 \mathrm{H}, \mathrm{s},-\mathrm{OCH}_{3}\right) .{ }^{13} \mathrm{C}-\mathrm{NMR}$ (DMSO- $\left.d_{6}, 125 \mathrm{MHz}\right) \delta: 182.5$ (C-4), 163.5 (C-2), 157.8 (C-7), 156.7 (C-5), 150.1 (C-8a), 132.6 (C-4'), 131.3 (C-1'), 129.8 (C-3', 5'), 128.2 (C-8), 126.8 (C-2', 6'), 105.5 (C-3), $104.2(\mathrm{C}-4 \mathrm{a}), 99.6(\mathrm{C}-6), 61.5\left(-\mathrm{OCH}_{3}\right)$. The ${ }^{1} \mathrm{H}-$ and ${ }^{13} \mathrm{C}-\mathrm{NMR}$ spectral data are consistent with published data $[34,35]$.

(3S)-3,5,4'-trihydroxy-7-methoxy-6-methyl homoisoflavonone (5). Colorless needle crystal $\left(\mathrm{CHCl}_{3}\right)$. $\mathrm{R}_{\mathrm{f}} 0.36(\mathrm{P} / \mathrm{E}=2: 1)[\alpha]_{\mathrm{D}}^{22}=+7.14 \pm 0.14^{\circ}\left(c=0.0100, \mathrm{CHCl}_{3}\right)$ ESI-MS: $m / z 329[\mathrm{M}-\mathrm{H}]^{-} . \mathrm{C}_{18} \mathrm{H}_{18} \mathrm{O}_{6}$. ${ }^{1} \mathrm{H}-\mathrm{NMR}\left(\mathrm{CDCl}_{3}, 500 \mathrm{MHz}\right) \delta: 7.09\left(2 \mathrm{H}, \mathrm{d}, 8.0 \mathrm{~Hz}, \mathrm{H}-2^{\prime}, 6^{\prime}\right), 6.78\left(2 \mathrm{H}, \mathrm{d}, 8.0 \mathrm{~Hz}, \mathrm{H}-3^{\prime}, 5^{\prime}\right), 6.10(1 \mathrm{H}$, s, H-8), $4.23(1 \mathrm{H}, \mathrm{d}, 11.0 \mathrm{~Hz}, \mathrm{H}-2 \mathrm{a}), 4.06(1 \mathrm{H}, \mathrm{d}, 11.0 \mathrm{~Hz}, \mathrm{H}-2 \mathrm{~b}), 3.91\left(3 \mathrm{H}, \mathrm{S},-\mathrm{OCH}_{3}\right), 2.96(2 \mathrm{H}, \mathrm{dd}$, $14 \mathrm{~Hz}, 5.0 \mathrm{~Hz}), 2.06\left(3 \mathrm{H}, \mathrm{s},-\mathrm{CH}_{3}\right) .{ }^{13} \mathrm{C}-\mathrm{NMR}\left(\mathrm{CDCl}_{3}, 125 \mathrm{MHz}\right) \delta: 198.3(\mathrm{C}-4), 166.5(\mathrm{C}-7), 161.1$ (C-8a), 160.1 (C-5), 154.9 (C-4'), 131.8 (C-2',6'), 126.2 (C-1'), 115.3 (C-3',5'), 106.5 (C-6), 100.2 (C-4a), 91.0 (C-8), 72.3 (C-3), $71.9(\mathrm{C}-2), 56.0\left(-\mathrm{OCH}_{3}\right), 40.8(\mathrm{C}-9), 6.9\left(-\mathrm{CH}_{3}\right)$. The ${ }^{1} \mathrm{H}-\mathrm{NMR}$ spectral data are consistent with published data [14].

Table 2. ${ }^{13} \mathrm{C}-\mathrm{NMR}$ data of compounds 1-3 (DMSO- $\left.d_{6}, 125 \mathrm{MHz}\right)$.

\begin{tabular}{cccc}
\hline Position & Compound 1 & Compound 2 & Compound 3 \\
\hline 1 & 126.3 & 126.9 & 126.9 \\
2 & 129.8 & 111.2 & 111.2 \\
3 & 116.2 & 148.3 & 148.3 \\
4 & 159.2 & 148.7 & 148.7 \\
5 & 116.2 & 116.1 & 116.1 \\
6 & 129.8 & 122.0 & 122.0 \\
7 & 139.3 & 139.3 & 139.4 \\
8 & 118.9 & 119.5 & 119.6 \\
9 & 166.1 & 165.8 & 166.0 \\
$1^{\prime}$ & 129.1 & 130.0 & 134.5 \\
$2^{\prime}$ & 130.0 & 129.9 & 127.6 \\
$3^{\prime}$ & 115.6 & 115.6 & 115.2 \\
$4^{\prime}$ & 156.0 & 156.1 & 156.9 \\
$5^{\prime}$ & 115.6 & 115.6 & 115.2 \\
$6^{\prime}$ & 130.0 & 129.9 & 127.6 \\
$7^{\prime}$ & 34.7 & 34.9 & 71.6 \\
$8^{\prime}$ & 41.2 & 41.1 & 47.5 \\
$-\mathrm{OCH}_{3}$ & & 56.0 & 55.9 \\
\hline
\end{tabular}

\subsection{Antioxidant Ability}

\subsubsection{DPPH Assay}

In this method, a microplate reader and 96 well plate were used to carry out the determination of the spectral absorption values. This assay is based on the classic method developed by Blois in 1958 [19]. Various forms of this method are widely used [36,37]. Unlike the commonly used methods, which are labor and time-consuming and reagent and sample-wasting, this microplate assay method is much more rapid, sample-saving and environmentally-friendly. In this method, methanolic DPPH solutions $(100 \mu \mathrm{g} / \mathrm{mL}, 50 \mu \mathrm{L})$ were added to samples of different concentration $(200 \mu \mathrm{L}, 12.5-100 \mu \mathrm{g} / \mathrm{mL})$. 
These solutions were gently mixed and incubated in the dark for $30 \mathrm{~min}$ at room temperature. Then the absorbances of the resulting solutions were measured at $517 \mathrm{~nm}$. For preparation of the standard curve, different concentrations of DPPH methanol solutions $(5-50 \mu \mathrm{g} / \mathrm{mL})$ were used. The DPPH concentration $(\mu \mathrm{g} / \mathrm{mL})$ in the reaction medium was calculated from the following calibration curve, determined by linear regression $\left(r^{2}: 0.9985\right)$ :

$$
\text { Absorbance }\left(\lambda_{517}\right)=0.022 \times\left[\mathrm{DPPH}^{*}\right]+0.0145
$$

The scavenging capability of test compounds was calculated using the following equation:

$$
\text { DDPH' scavenging activity }(\%)=\left(1-\frac{\lambda_{517-\mathrm{S}}}{\lambda_{517-\mathrm{C}}}\right) \times 100
$$

where $\lambda_{517-\mathrm{C}}$ is absorbance of a control with no radical scavenger and $\lambda_{517-\mathrm{S}}$ is absorbance of the remaining DPPH in the presence of scavenger.

\subsubsection{ABTS Assay}

The ABTS assay was carried out using a method based on the original and classic method developed by Miller in 1993 [38] with some modifications. The ABTS radical should be preformed by reacting equal volumes of $1.1 \mathrm{mg} / \mathrm{mL}$ aqueous $\mathrm{ABTS}$ and $0.68 \mathrm{mg} / \mathrm{mL}$ potassium persulfate $\left(\mathrm{K}_{2} \mathrm{~S}_{2} \mathrm{O}_{8}\right)$, and then storing in the dark for $6 \mathrm{~h}$ at room temperature, as described by Gülçin [6]. Then ABTS ${ }^{++}$ solutions $(50 \mu \mathrm{L})$ were added to samples of different concentrations $(200 \mu \mathrm{L}, 12.5-100 \mu \mathrm{g} / \mathrm{mL})$. These solutions were gently mixed and incubated in the dark for $30 \mathrm{~min}$ at room temperature. Then the absorbances of the resulting solutions were measured at $734 \mathrm{~nm}$. Different concentrations of ABTS radical solutions $(55-220 \mu \mathrm{g} / \mathrm{mL})$ were used to prepare the standard curve. The ABTS radical concentration $(\mu \mathrm{g} / \mathrm{mL})$ in the reaction medium was calculated from the following calibration curve, determined by linear regression $\left(r^{2}: 0.9985\right)$ :

$$
\text { Absorbance }\left(\lambda_{734}\right)=0.0118 \times\left[\mathrm{ABTS}^{\cdot+}\right]+0.109
$$

The scavenging capability of test compounds was calculated using the following equation:

$$
\mathrm{ABTS}^{++} \text {scavenging activity }(\%)=\left(1-\frac{\lambda_{734-\mathrm{S}}}{\lambda_{734-\mathrm{C}}}\right) \times 100
$$

where $\lambda_{734-\mathrm{C}}$ is absorbance of a control with no radical scavenger and $\lambda_{734-\mathrm{S}}$ is absorbance of the remaining ABTS in the presence of scavenger.

\section{Conclusions}

Phenolic components of $L$. muscari were studied for the first time. Three amides, one flavone and one homoisoflavonone were isolated and their antioxidant activities were evaluated using two microplate assay methods. $N$-trans-feruloyltyramine (2) and $N$-trans-feruloyloctopamine (3) showed effective activity and the structure-activity relation investigation indicates that the $-\mathrm{OCH}_{3}$ group at $\mathrm{C}-3$ affects the antioxidant activity. 


\section{Supplementary Materials}

Supplementary materials can be accessed at: http://www.mdpi.com/1420-3049/17/2/1797/s1.

\section{Acknowledgements}

This project was supported by National "Twelfth Five-Year" Plan for Science and Technology Program of China 2009BAI73B02. We thank Zhang. J. from National Institutes for Food and Drug Control, Beijing 100050, for the identification of the investigated medicinal herb.

\section{Conflict of Interest}

The authors declare no conflict of interest.

\section{References and Notes}

1. Dai, J.; Mumper, R.J. Plant Phenolics: Extraction, Analysis and Their Antioxidant and Anticancer Properties. Molecules 2010, 15, 7313-7352.

2. Gülçin, İ.; Alici, H.A.; Cesur, M. Determination of in vitro antioxidant and radical scavenging activities of propofol. Chem. Pharm. Bull. 2005, 53, 281-285.

3. Moure, A.; Cruz, J.M.; Franco, D. Natural antioxidants fromresidual sources. Food Chem. 2001, $72,145-171$.

4. Oktay, M.; Gülçin, İ.; Küfrevioğlu, Ö.İ. Determination of in vitro antioxidant activity of fennel (Foeniculum vulgare) seed extracts. LWT-Food Sci. Technol. 2003, 36, 263-271.

5. Celik, B.; Lee, J.H.; Min, D.B. Effects of light, oxygen and $\mathrm{pH}$ on the 2,2-diphenyl-1-picrylhydrazyl (DPPH) method to evaluate antioxidants. J. Food Sci. 2003, 68, 487-490.

6. Gülçin, İ. Antioxidant activity of 1-adrenaline: A structure-activity insight. Chem. Biol. Interact. 2009, 179, 71-80.

7. Havsteen, B.H. The biochemistry and medicinal significance of the flavonoids. Pharmacol. Ther. 2002, 96, 67-202.

8. Li, X.L.; Zhou, A.G.; Han, Y. Anti-oxidation and anti-microorganism activities of purification polysaccharide from Lygodium japonicum in vitro. Carbohydr. Polym. 2006, 66, 34-42.

9. Yu, B.Y.; Xu, G.J.; Jin, R.L.; Xu, L.S. Drug resources and identification of commercial drugs on Radix Ophiopogonis (in Chinese with English abstract). J. Chin. Pharm. Univ. 1991, 22, 150-153.

10. Tian, Y.Q.; Kou, J.P.; Li, L.Z.; Yu, B.Y. Anti-inflammatory effects of aqueous extract from Radix Liriope muscari and its major active fraction and component. Chin. J. Nat. Med. 2011, 9, 222-226.

11. Yu, B.Y.; Hirai, Y.; Shoji, J.Z.; Xu, G.J. Comparative studies on the constituents of ophiopogonis tuber and its congeners. VI. Studies on the constituents of the subterranean part of Liriope spicata var. prolifera and L. muscari. Chem. Pharm. Bull. 1990, 38, 1931-1935.

12. Cheng, Z.H.; Wu, T.; Yu, B.Y.; Xu, L.S. Studies on Chemical constituents of Liriope muscari (in Chinese). Zhong Cao Yao 2005, 36, 823-826.

13. Cheng, Z.H.; Wu, T.; Guo, Y.L.; Yu, B.Y.; Xu, L.S. Two new steroidal glycosides from Liriope muscari. Chin. Chem. Lett. 2006, 17, 31-34. 
14. Watanabe, Y.; Sanada, S.; Ida, Y.; Shoji, J. Comparative studies on the constituents of ophiopogonis tuber and its congeners. IV. Studies on the homoisoflavonoids of the subterranean part of Ophiopogon ohwii Okuyama and O. jaburan (Kunth) Lodd. Chem. Pharm. Bull. 1985, 33, 5358-5363.

15. Böhler, P.; Tamm, C. The homo-isoflavones, a new class of natural product. Isolation and structure of eucomin and eucomol. Tetrahedron Lett. 1967, 36, 3479-3483.

16. Weber, H.P.; Heller, W.; Tamm, C. Homoisoflavanones. V. Crystal and molecular structure of (-)7-O-(p-Bromophenacyl)-eucomol. The absolute configuration of (-)-eucomol). Helv. Chim. Acta 1977, 60, 1388-1392.

17. Hernández, J.C.; León, F.; Estévez, F.; Quintana, J.; Bermejo, J. A homoisoflavonoid and a cytotoxic saponin from Dracaena draco. Chem. Biodivers. 2006, 3, 62.

18. Oyaizu, M. Studies on product of browning reaction prepared from glucose amine. Jpn. J. Nutr. 1986, 44, 307-315.

19. Blois, M.S. Antioxidant determinations by the use of a stable free radical. Nature 1958, 26, 1199-1200.

20. Re, R.; Pellegrini, N.; Proteggente, A. Antioxidant activity applying an improved ABTS radical cation decolourization assay. Free Radical Biol. Med. 1999, 26, 1231-1237.

21. Cheng, M.J.; Wu, M.D.; Chen, I.S.; Yuan, G.F. A new sesquiterpene isolated from the extracts of the fungus Monascus pilosus-fermented rice. Nat. Prod. Res. 2010, 24, 750-758.

22. Ichikawa, M.; Ryu, K.; Yoshida, J.; Ide, N.; Kodera, Y.; Sasaoka, T.; Rosen, R.T. Identification of six phenylpropanoids from garlic skin as major antioxidants. J. Agric. Food Chem. 2003, 51, 7313-7317.

23. Tomosaka, H.; Chin, Y.W.; Salim, A.A.; Keller, W.J.; Chai, H.; Kinghorn, A.D. Antioxidant and cytoprotective compounds from Berberis vulgaris (Barberry). Phytother. Res. 2008, 22, 979-981.

24. Li, Y.; Wang, C.L.; Wang, F.F.; Dong, H.L.; Guo, S.X.; Yang, J.S.; Xiao, P.G. Phenolic components and flavanones from Dendrobium candid (in Chinese with English abstract). Chin. Pharm. J. 2010, 45, 975-979.

25. Sato, T.; Kawamoto, A.; Tawura, A.; Tatsumi, Y.; Fujii, T. Mechanism of antioxidant action of Pueraria Glycoside (PG-1) (an isoflavonoid) and Mangiferin (a xanthoniod). Chem. Pharm. Bull. 1992, 40, 721-724.

26. Lien, E.J.; Ren, S.; Bui, H.H.; Wang, R. Quantitative structure-activity relationship analysis of phenolic antioxidants. Free Radic. Biol. Med. 1999, 26, 285-294.

27. Wu, L.; Ding, X.P.; Zhu, D.N.; Yu, B.Y.; Yan, Y.Q. Study on the radical scavengers in the traditional Chinese medicine formula Shengmai San by HPLC-DAD coupled with chemiluminescence (CL) and ESI-MS/MS. J. Pharm. Biomed. Anal. 2010, 52, 438-445.

28. Gao, M.; Wang, X.L.; Gu, M. Separation of polyphenols using porous polyamide resin and assessment of mechanism of retention. J. Sep. Sci. 2011, 34, 1853-1858.

29. Holzbach, J.C.; Lopes, L.M.X. Aristolactams and alkamides of Aristolochia gigantean. Molecules 2010, 15, 9462-9472.

30. Yang, J.Q.; Wang, Y.; Yan, C.; Wang, N.N.; Hao, X.Y. Chemical constituents from Reineckia carnea Kunth (in Chinese with English abstract). Nat. Prod. Res. Dev. 2010, 22, 245-247. 
31. Munoz, O.; Piovano, M.; Garbarino, J.; Heuwing, V.; Breitmaier, E. Traopane alkaloids from Schizanthus Litoralis. Phytochemistry 1996, 43, 709-713.

32. King, R.R.; Calhoun, L.A. Characterization of cross-linked hydroxycinnamic acid amides isolated from potato common scab lesions. Phytochemistry 2005, 66, 2468-2473.

33. Lee, D.G.; Park, Y.; Kim, M.R.; Jung, H.J.; Seu, Y.B.; Hahm, K.S.; Woo, E.R. Anti-fungal effects of phenolic amides isolated from the root bark of Lycium chinense. Biotechnol. Lett. 2004. 26, $1125-1130$.

34. Leslie, J.H.; Guat-Lee, S.; Keng-Yeow, S. 5,7-Dihydroxy-8-methoxyflavone from Tetracera indica. Planta Med. 1994, 60, 493-494.

35. Huang, W.; Tan, G.S.; Xu, K.P.; Li, F.S.; Li, Z.K.; Liu, Y.P. Cytotoxic constituents from the root of Ardisia crisp (in Chinese with English abstract). Nat. Prod. Res. Dev. 2010, 22, 949-951.

36. Gülçin, İ. Antioxidant and antiradical activities of 1-carnitine. Life Sci. 2006, 78, 803-811.

37. Shimada, K.; Fujikawa, K.; Yahara, K.; Nakamura, T. Antioxidative properties of xanthin on autoxidation of soybean oil in cyclodextrin emulsion. J. Agric. Food Chem. 1992, 40, 945-948.

38. Miller, N.J.; Rice-Evans, C.A.; Davies, M.J. A novel method for measuring antioxidant capacity and its application to monitoring the antioxidant status in premature neonates. Clin. Sci. 1993, 84, $407-412$.

Sample Availability: Samples of the crude extracts and pure compounds are available from the authors.

(C) 2012 by the authors; licensee MDPI, Basel, Switzerland. This article is an open access article distributed under the terms and conditions of the Creative Commons Attribution license (http://creativecommons.org/licenses/by/3.0/) 